\title{
Anti-bacterial, free radical scavenging activity and cytotoxicity of acetone extracts of Grewia flava.
}

\author{
Stella Makgabo Lamola ${ }^{1}$, Jean Paul Dzoyem ${ }^{1,2}$, Francien Botha ${ }^{1}$, Candice van Wyk ${ }^{3}$
}

1. Phytomedicine Programme, Department of Paraclinical Sciences, Faculty of Veterinary Science, University of Pretoria, Private Bag X04, Onderstepoort 0110, Pretoria, South Africa.

2. Department of Biochemistry, Faculty of Science, University of Dschang, P.O. Box 67, Dschang, Cameroon

3. Department of Community Dentistry, Faculty ofHealth Sciences, University of Pretoria, Pretoria, P. O. Box 1266, Pretoria 0001, South Africa

\begin{abstract}
Background: Bacterial infections of the gastrointestinal tract (GIT) cause vomiting, diarrhoea and even systemic disease. There is a need for the development of natural products into alternative and safer medicines.

Objectives: This study evaluated the anti-microbial activity of extracts prepared from berries, leaves,bark and roots of the edible plant Grewia flava.

Methods: The anti-bacterial activity was evaluated by the broth microdilution method. Anti-oxidant activity of the most active extracts was performed by 2, 2-diphenyl-1-picrylhydrazyl (DPPH) assay. The cytotoxicity of the extracts was determined using the 3-(4,5-dimethylthiazol-2-yl)-2,5-diphenyltetrazolium bromide (MTT) assay.

Results: The acetone extracts of the leaves and roots showed the best activity with MIC values as low as $0.03 \mathrm{mg} / \mathrm{mL}$ against Staphylococcus aureus and Salmonella typhimurium and $0.07 \mathrm{mg} / \mathrm{mL}$ against Bacillus cereus, Escherichia coli and Staphylococcus aureus. Quantitative analysis of the scavenging ability showed that acetone extracts exhibited good free radical scavenging activity in a dose-dependent manner. The berries extract had the highest $\mathrm{LC}_{50}$ (lowest toxicity) of $551.6868 \mu \mathrm{g} / \mathrm{mL}$.

Conclusion: Acetone extract of leaves and roots of Grewia flava contain anti-microbial and anti-oxidant compounds and could therefore be used as a natural product with little toxicity to host cells.

Keywords: Extracts, anti-microbial, cytotoxicity, enteric pathogens, Grewia flava.

DOI: https://dx.doi.org/10.4314/ahs.v17i3.22

Cite as: Lamola SM, Droyem JP, Botha F, Wyk Cv. Antibacterial, free radical scavenging activity and cytotoxicity of acetone extracts of Grewiaflava. Afri Health Sci. 2017;17(3): 790-796. https:/ / dx.doi.org/10.4314/abs.v17i3.22
\end{abstract}

\section{Introduction}

For centuries the indigenous people of South Africa have relied on herbal medicine for all their primary health care, and it is estimated that millions of South Africans still use traditional remedies from as many as 700 indigenous plant species ${ }^{1}$. The use of medicinal plants in the world contributes significantly to primary health care and traditional medicines are part of the cultural and religious beliefs, they are easily available and affordable to rural

\footnotetext{
Corresponding author:

Jean Paul Dzoyem,

Department of Biochemistry,

Faculty of Science, University of Dschang,

P.O. Box 67, Dschang, Cameroon

Tel: +237 676091031,

E.mail: jpdzoyem@yahoo.fr
}

people ${ }^{2,3}$. Therefore the level of sanitation, hygiene and living conditions in most rural areas are not comparable to those of urban areas ${ }^{4}$. There are numerous bacteria species that can infect the digestive system, such as Salmonella spp., Escherichia coli, Staphylococcus aureus ${ }^{5}$. The search for and development of new anti-biotics that will target resistant bacterial strains are needed. Therefore, the screening of plant extracts for antibacterial compounds is very important and relevant ${ }^{6}$. Anti-microbial substances from natural sources like plants have been investigated to achieve higher levels of food safety ${ }^{7}$. Medicinal plants are assumed to be non-toxic and regarded safe due to their natural origin and the long use in traditional medicine to treat various forms of diseases ${ }^{8,9}$. Scientific studies on efficacy and safety of some of the medicinal plants indicated that there are many phytochemicals that have cytotoxicity, genotocixity and carcinogenic effects when used chronically ${ }^{10}$. License (https://creativecommons.org/licenses/by/4.0), which permits unrestricted use, distribution, and reproduction in any medium, provided the original work is properly cited.
} 
The genus Grewia is from the family Malvaceae and a major angiosperm group (flowering plants) with approximately 400 species of flowering plants, shrubs, and trees that are widely distributed in sub-tropical and tropical regions ${ }^{11,12}$. A number of species of the genus Grewia have been reported to be used as medicinal agents to treat several diseases such as skin diseases, hypertension, ulcers and diarrhoea, and compounds were isolated from various species of the Grewia ${ }^{13}$. Grewia flava DC. is commonly known as the "brandy bush" or "velvet raisin" (English), "fluweelrosyntjie/wilderosyntiie" (Afrikaans) and "moretlwa" (Tswana and Sepedi) ${ }^{14}$. The Grewia flava fruits are mashed, soaked for a while in water and eaten as porridge by the San (Bushmen). The beer prepared from the berries is called "Khadi"". There is a diverse possibility that the plant involved has ethno-medicinal familiarity to the indigenous people and the potential pharmacological interactions are an area in serious need of in-depth study ${ }^{15}$. To the best of the author's knowledge, no study has been focused on the pharmacological activity of Grewia flava. The aim of the study was to analyze the anti-microbial, the free radical scavenging activity and the cytotoxicity of extracts from the edible plant Grewia flava.

\section{Materials and methods Plant materials}

Berries, leaves, barks and roots from the edible plant Grewia flava were collected from an open field at Moletjie Ga-Phago near Lonsdale, Polokwane, Limpopo (Grid 2329CA $\left.23^{\circ} 00^{\prime}, 29^{\circ} 00^{\prime} \mathrm{E}\right)$. The plant was identified and authenticated by Elsa van Wyk from the University of Pretoria and a voucher specimen, PRU 119004, is maintained at the HGWJ Schweickerdt Herbarium of the Department of Plant Science, University of Pretoria. Plant material was dried at room temperature in the shade and ground to powder using a Kika-werk M20, bench top grinder. Powdered materials were stored in closed honey jars at room temperature until use.

\section{Extraction}

One gram of each plant part was macerated in $10 \mathrm{~mL}$ of acetone, methanol, acetyl acetate and water in polyester centrifuge tubes. The tube was vigorously shaken for 30 min on an orbital shaker, then centrifuged at $4000 \times \mathrm{g}$ for $10 \mathrm{~min}$ and the supernatant was filtered using Whatman No.1 filter paper before being transferred into preweighed glass containers. This was repeated thrice and solvent was removed by evaporation under a stream of air in a fume hood at room temperature to produce the dried extract.

\section{TLC fingerprinting}

TLC-vanillin method of Kotze and Eloff was used ${ }^{16}$. The dried extracts were weighed and the mass of the dried residues recorded. Ten milligrams $(10 \mathrm{mg})$ of the dried extract residue was weighed and a $10 \mathrm{mg} / \mathrm{mL}$ concentration extract solution was prepared. Each extract $(10 \mu \mathrm{L})$ was loaded on the base of the thin layer chromatography silica gel 60 F254 aluminium backed plate (Merck). Different mobile systems were used for separation of the compounds namely: Ethyl acetate: methanol: water (EMW, polar system); chloroform: ethyl acetate: formic acid (CEF, intermediate system); and benzene: ethanol: acetic acid (BEA, non-polar system). The plates were sprayed with vanillin in sulphuric acid $(0.1 \mathrm{~g}$ vanillin in $28 \mathrm{ml}$ methanol and $1 \mathrm{ml} \mathrm{H}_{2} \mathrm{SO}_{4}$ ) for visualising different compounds in the extracts.

\section{Anti-microbial activity}

The four bacterial strains used included two Gram-positive bacteria (Staphylococcus aureus ATCC 29213, Bacillus cereus ATCC14579) and two Gram-negative bacteria (Escherichia coli ATCC 25922 and Salmonella typhimurium ATCC 14028). The minimum inhibitory concentration (MIC) was determined as previously described ${ }^{17}$.

\section{Anti-oxidant activity \\ Qualitative analysis of the anti-oxidant activity}

The TLC-DPPH method and TLC-vanillin method of Masoko and Eloff was used ${ }^{18}$. The dried extracts were weighed and the mass of the dried residues recorded. Ten milligrams $(10 \mathrm{mg})$ of the dried extract residue was weighed and a $10 \mathrm{mg} / \mathrm{mL}$ concentration extract solution was prepared. Each extract $(10 \mu \mathrm{L})$ was loaded on the base of the thin layer chromatography silica gel 60 F254 aluminium backed plate (Merck). Different mobile systems were used for separation of the compounds namely: Ethyl acetate: methanol: water (EMW, polar system); chloroform: ethyl acetate: formic acid (CEF, intermediate system); and benzene: ethanol: acetic acid (BEA, non-polar system). The plates were sprayed with $0.2 \% \mathrm{DPPH}$ in methanol to determine the free radical scavenging activity. Other plates were sprayed with vanillin in sulphuric acid $\left(0.1 \mathrm{~g}\right.$ vanillin in $28 \mathrm{ml}$ methanol and $\left.1 \mathrm{ml} \mathrm{H}_{2} \mathrm{SO}_{4}\right)$ for visualising different compounds in the extracts. 


\section{DPPH radical scavenging activity}

2,2-diphenyl-1-picrylhydrazyl (DPPH) radical-scavenging activity was determined using the method proposed by Brand-Williams ${ }^{19}$. One hundred and sixty microlitres of the methanolic solution of DPPH $(0.04 \mathrm{mg} / \mathrm{mL}$, ) was added to $40 \mu \mathrm{l}$ ascorbic acid and Trolox at concentrations of $1.0-200 \mu \mathrm{g} / \mathrm{mL}$ (positive controls), and different concentrations of crude extracts $(3.9-500 \mu \mathrm{g} / \mathrm{mL})$. After 30 minutes the absorbance was measured at 517 nm using a Biotek microplate reader. Ascorbic acid was used as positive control, methanol as negative control and extract without DPPH as blank. Scavenging capacity $(\%)=100-[($ absorbance of sample - absorbance of sample blank) $\times 100 /$ (absorbance of control)-(absorbance of control blank)]. The $\mathrm{IC}_{50}$ values were calculated from the graph plotted as inhibition percentage against the concentration.

\section{Cytotoxicity}

Cytotoxicity of extracts was evaluated against Vero cells using the 3-(4,5-dimethylthiazol-2-yl)-2,5-diphenyltetrazolium bromide (MTT) assay as previously described ${ }^{17}$. Cells were seeded at a density of $1 \times 10^{5}$ cells $/ \mathrm{ml}(100 \mu \mathrm{l})$ in 96-well microtitre plates and incubated at $37^{\circ} \mathrm{C}$ and $5 \%$ $\mathrm{CO}_{2}$ in a humidified environment. After $24 \mathrm{~h}$ incubation, extracts $(100 \mu \mathrm{l})$ at varying final concentrations were added to the wells containing cells. Doxorubicin was used as a positive reference. A suitable blank control with equivalent concentrations of acetone was also included and the plates were further incubated for $48 \mathrm{~h}$ in a $\mathrm{CO}_{2}$ incubator. Thereafter, the medium in each well was aspirated from the cells, which were then washed with PBS, and finally fresh medium $(200 \mu \mathrm{l})$ was added to each well. Then, 30 $\mu \mathrm{l}$ of MTT $(5 \mathrm{mg} / \mathrm{ml}$ in PBS) was added to each well and the plates were incubated at $37^{\circ} \mathrm{C}$ for $4 \mathrm{~h}$. The medium was aspirated from the wells and DMSO was added to solubilize the formed formazan crystals. The absorbance was measured on a BioTek Synergy microplate reader at $570 \mathrm{~nm}$. Cell growth inhibition for each extract was expressed in terms of $\mathrm{LC}_{50}$ values, defined as the concentration that caused $50 \%$ of inhibition of cell viability. The selectivity index (SI) values were calculated by dividing cytotoxicity $\mathrm{LC}_{50}$ values by the MIC values $\left(\mathrm{SI}=\mathrm{LC}_{50} /\right.$ MIC). Tests were carried out in quadruplicate and each experiment was repeated thrice.

\section{Statistical analysis}

All experiments were conducted thrice in triplicates and values expressed as mean \pm standard deviation (SD). Statistical analysis was performed by using one way ANOVA and results were compared using the Student's t-Test at a $5 \%$ significance level.

\section{Results and discussion Anti-microbial activity}

The anti-bacterial activity of the Grewia flava plant extracts parts is shown in Table 1. The results showed that the activity of the extracts against the four enteric pathogens varied from weak to significant with MIC values ranged from $>2.5$ to $0.03 \mathrm{mg} / \mathrm{mL}$. The acetone extracts of the leaves and roots had better activity with MIC values as low as $0.03 \mathrm{mg} / \mathrm{mL}$ against $S$. aureus and $S$. typhimurium and $0.07 \mathrm{mg} / \mathrm{mL}$ against B. cereus, E. coli and S. aureus. Acetone was previously reported to be the best extractant of anti-microbial compounds in addition to its low toxicity to pathogens ${ }^{20}$. Methanol extracts also had significant activity with the lowest inhibition at a concentration of 0.07 $\mathrm{mg} / \mathrm{mL}$ from the leaves, bark and roots against E. coli, $B$. cereus and $S$. aureus. Acetyl acetate root extract had an effective activity against $S$. aueus and $E$. coli with a minimal concentration of $0.07 \mathrm{mg} / \mathrm{mL}$. Water extracts were not effective against the enteric pathogens. 
Table 1: Minimal inhibitory concentrations $(\mathrm{mg} / \mathrm{mL})$ of the berries, leaves, bark and roots extracts of Grewia flava against four enteric pathogens.

\begin{tabular}{llcccc}
\hline Plant parts & Solvents & \multicolumn{4}{c}{ MIC $(\mathbf{m g} / \mathbf{m L})$} \\
\cline { 3 - 6 } Berries & Acetone & 0.62 & \multicolumn{1}{c}{$\boldsymbol{B} \boldsymbol{c}$} & $\boldsymbol{E} \boldsymbol{c}$ & $\boldsymbol{S T}$ \\
& Methanol & $>2.5$ & $>2.5$ & 0.31 & 1.25 \\
& Acetyl acetate & 0.15 & 0.15 & 0.31 & 0.31 \\
& Water & 0.31 & 1.25 & 0.15 & 0.62 \\
Leaves & Acetone & $\mathbf{0 . 0 3}$ & $\mathbf{0 . 0 7}$ & $\mathbf{0 . 0 7}$ & $\mathbf{0 . 0 3}$ \\
& Methanol & $\mathbf{0 . 0 7}$ & 0.62 & $\mathbf{0 . 0 7}$ & 0.15 \\
& Acetyl acetate & 0.62 & 1.25 & 0.31 & 1.25 \\
Barks & Water & 0.31 & $>2.5$ & 0.31 & 1.25 \\
& Acetone & $\mathbf{0 . 0 7}$ & 0.31 & 0.15 & 0.62 \\
& Methanol & 0.31 & 0.15 & 0.31 & 0.31 \\
Roots & Acetyl acetate & 0.62 & 1.25 & 0.15 & 1.25 \\
& Water & $>2.5$ & $>2.5$ & 1.25 & $>2.5$ \\
& Acetone & $\mathbf{0 . 0 3}$ & $\mathbf{0 . 0 7}$ & $\mathbf{0 . 0 7}$ & 0.62 \\
& Methanol & $\mathbf{0 . 0 7}$ & 0.31 & $\mathbf{0 . 0 7}$ & 0.15 \\
Gentamicin & Acetyl acetate & 0.15 & 0.31 & 0.62 & 0.31 \\
$(\boldsymbol{\mu g} / \mathbf{m L})$ & Water & 0.31 & $>2.5$ & 1.25 & 0.62 \\
& & 0.2 & 0.8 & 0.4 & 1.56 \\
\hline \hline
\end{tabular}

BC: Bacillus cereus, EC: Escherichia coli, ST: Staphylococcus aureus, ST: Salmonella typhimurium. in bold are MIC values $<0.1 \mathrm{mg} / \mathrm{mL}$.

To the best of the author's knowledge, this is the first report on the anti-bacterial activity of extracts from Grewia flava species. However, several previous studies reported the antibacterial activity of extracts from the genus Gre$w i a^{21}$. For instance, Gupta et al. ${ }^{22}$ reported the activity of different extracts of $G$. asiatica against four Gram positive (Bacillus subtilis, B. cereus, Staphylococcus aureus, Enterococcus faecalis) and five Gram negative bacteria (Escherichia coli, Listeria monocytogeneses, Salmonella typhimurium, Shigella flexneri and Pseudomonas aerugenosa).

Although the methanol extracts were also effective against the enteric pathogens, the acetone extracts were the most active and were selected for further studies.

\section{TLC fingerprinting}

In order to observe the major compounds group within the most active extracts, qualitative phytochemical analysis using TLC fingerprinting was developed in three dif- ferent systems: a non-polar system (BEA), an intermediate system (CEF) and a polar system (EMW). Qualitative screening of acetone extracts of the Grewia flava plant parts was performed to obtain thin layer chromatography (TLC) fingerprints of each investigated extract. Results are presented in Figure 1. The chromatogram reveals a mixture of compounds where the system separated the non-polar compounds finely, which exhibited different colours when reacting to the Vanillin $/ \mathrm{H}_{2} \mathrm{SO}_{4}$ spray reagent. The classes of compounds extracted include the terpenoids, which are purple or bluish purple ${ }^{23}$. The EMW system, which is a highly polar system, was used to separate the water extracts, because water is a highly polar solvent, most of the compounds extracted were polar to highly polar compounds. Some secondary metabolites and isolated compounds present in Grewia species include pelargonidin 3,5-diglucoside, naringenin-7-O- $\beta$-D-glucoside, tannins, catechins, and cyanidin-3-glucoside ${ }^{24}$, betulin, lupeol, lupenone and friedelin ${ }^{25}$. 


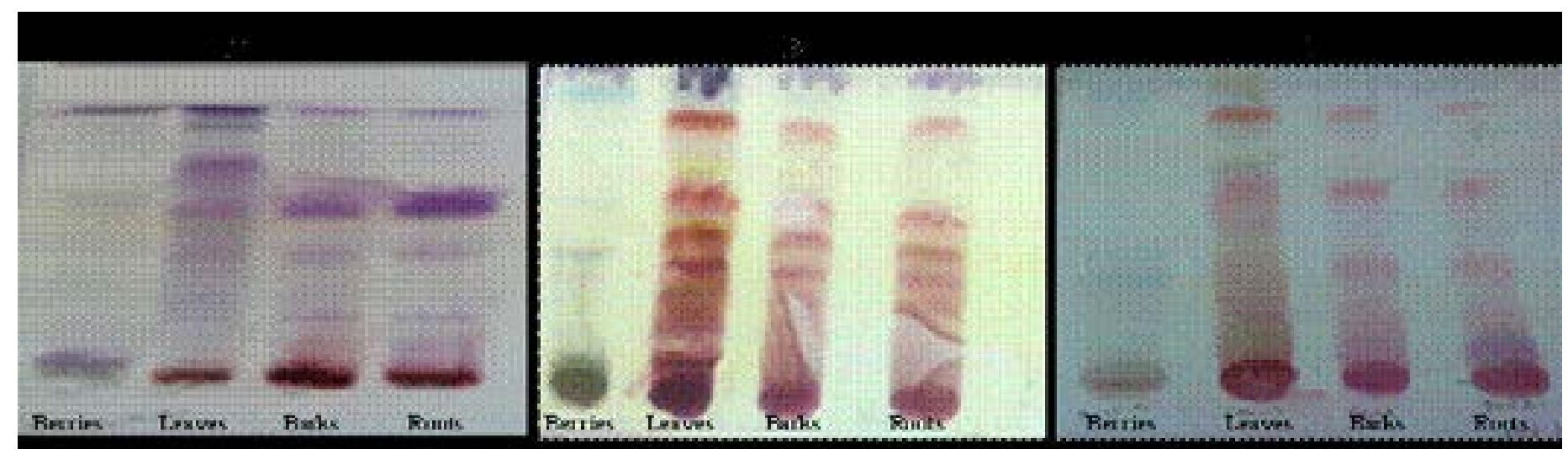

Figure 1: TLC chromatogram of the berries, leaves, bark and roots extracts developed in the BEA system (A) in the EMW system (B) and in the CEF system (C) and sprayed with vanillin-- $\mathrm{H}_{2} \mathrm{SO}_{4}$.

\section{Anti-oxidant activity}

The qualitative anti-oxidants screening of spraying DPPH on TLC plates indicates the presence of antioxidant compounds in the crude extracts. The anti-oxidant compounds are visualised as yellow spots against the purple background of DPPH, as shown in Figure 2. The number of anti-oxidant compounds identifiable depends on the mobile system used for separation. The Roots extract showed a range of compounds extracted. Most of the antioxidant compounds in this species were polar phenolics compounds, and were better separated with a polar mobile system (CEF).

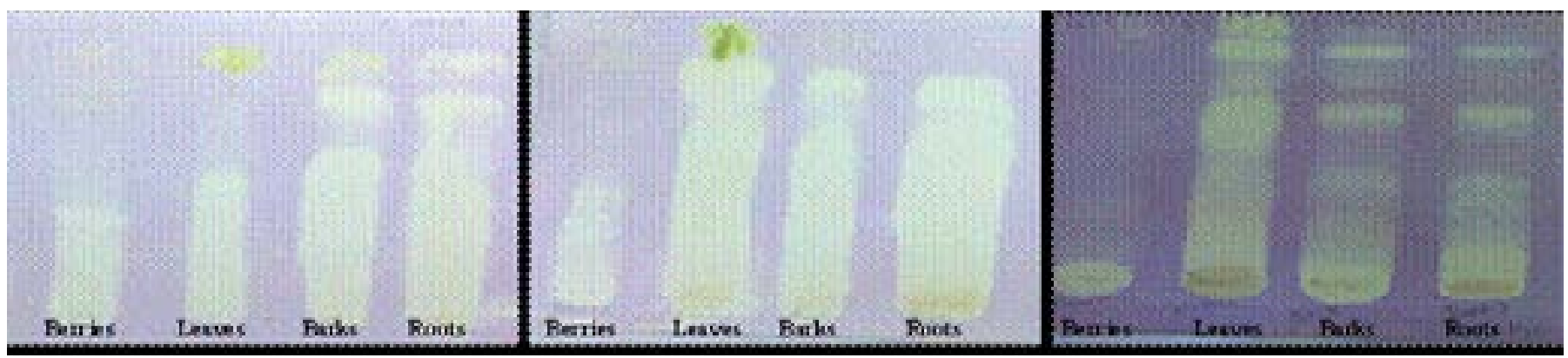

Figure 2: TLC chromatogram of the berries, leaves, bark and roots extracts developed in theBEA system (A) in the EMW system (B) and in the CEF system (C) and sprayed with DPPH.

Quantitative analysis of the scavenging ability showed that acetone extracts exhibited good free radical scavenging activity in a dose-dependent manner. The IC50 values ranged from $250.53 \mu \mathrm{g} / \mathrm{mL}$ to $70.09 \mu \mathrm{g} / \mathrm{mL}$. Root extract exhibited the highest antioxidant activity $\left(\mathrm{IC}_{50}\right.$ values of $70.09 \mu \mathrm{g} / \mathrm{mL}$ ) which was consistent with the activity on TLC-DPPH sprayed plates. However this activity was lower than that of ascorbic acid used as control $\left(\mathrm{IC}_{50}\right.$ value of $9.14 \mu \mathrm{g} / \mathrm{mL}$ ). The leaves extract had a high DPPH radical activity compared to the berries and bark. No previous study has been focused on the anti-oxidant activity of Grewia flava. However, the anti-oxidant activity of related species is well documented ${ }^{26}$.

\section{Cytotoxicity}

The cytotoxicity was determined using the in vitro assay and tested against Vero monkey kidney cells. The $\mathrm{LC}_{50}$ values and the selectivity index calculated are presented in Table 2. The cytotoxicity evaluation is important in the biological activity testing to ensure that the biological activity of the plant extract is not due to a general metabolic toxic effect. In this study, the $\mathrm{LC}_{50}$ values ranged from 402.13 to $551.68 \mu \mathrm{g} / \mathrm{mL}$, while the SI values were between 0.05 and 7.88. The berries extract had the highest $\mathrm{LC}_{50}$ (lowest toxicity) of $551.68 \mu \mathrm{g} / \mathrm{mL}$. The results indicate that the extracts of Grewia flava are less toxic to Vero cells at the tested concentration compared to doxorubicin used as control $\left(\mathrm{IC}_{50}\right.$ value of $\left.3.02 \mu \mathrm{g} / \mathrm{mL}\right)$ and therefore confirm the safety of the use of this edible plant. 
Table 2: Antioxidant activity $\left(\mathrm{IC}_{50}\right.$ in $\left.\mu \mathrm{g} / \mathrm{mL}\right)$, cytotoxicity against Vero cells $\left(\mathrm{LC}_{50}\right.$ in $\mu \mathrm{g} / \mathrm{mL}$ ) and selectivity index (SI) of Grewia flava acetone extracts.

\begin{tabular}{lcccccc}
\hline & & & \multicolumn{4}{c}{ Selectivity index $\left(\mathbf{L C} \mathbf{C}_{\mathbf{5 0}} / \mathbf{M I C}\right)$} \\
\cline { 5 - 7 } Extracts & $\mathbf{I C}_{\mathbf{5 0}}(\boldsymbol{\mu g} / \mathbf{m L})$ & $\mathbf{L C}_{\mathbf{5 0}}(\boldsymbol{\mu g} / \mathbf{m L})$ & $\boldsymbol{B c}$ & $\boldsymbol{E c}$ & $\boldsymbol{S a}$ & $\boldsymbol{S T}$ \\
\hline Berries & $222.34 \pm 35.32^{\mathrm{a}}$ & $551.68 \pm 22.55^{\mathrm{a}}$ & 0.41 & 4.03 & 0.50 & 0.50 \\
Leaves & $123.87 \pm 26.18^{\mathrm{b}}$ & $507.21 \pm 12.65^{\mathrm{b}}$ & 7.88 & 1.00 & 2.33 & 1.00 \\
Bark & $250.53 \pm 43.08^{\mathrm{c}}$ & $452.69 \pm 33.02^{\mathrm{c}}$ & 1.46 & 2.07 & 2.14 & 0.11 \\
Roots & $70.09 \pm 17.15^{\mathrm{d}}$ & $402.13 \pm 23.02^{\mathrm{d}}$ & 5.74 & 1.00 & 2.33 & 0.05 \\
Doxorubicin & nd & $3.02 \pm 0,03^{\mathrm{e}}$ & nd & nd & nd & nd \\
Vitamin C & $9.14 \pm 3.24^{\mathrm{e}}$ & nd & nd & nd & nd & nd \\
\hline
\end{tabular}

BC: Bacillus cereus, EC: Escherichia coli, ST: Staphylococcus aureus, ST: Salmonella typhimurium. nd $=$ not detected. Data represent the mean $\pm \mathrm{SD}$ of three independent experiments; values with different letters are significantly different at $\mathrm{p}<0.05$.

\section{Conclusion}

The indigenous edible plant Grewia flava was shown to be non-toxic at the tested concentrations. Root and leaves extracts possess significant antibacterial activity particularly against Staphylococcus aureus and therefore could be used to combat bacterial diseases. Further studies have to be conducted to confirm the safety and to isolate the bioactive compound(s).

\section{Conflict of interest}

The authors have declared that no competing interests exist.

\section{References}

1. Bhat RB. Medicinal plants and traditional practices of Xhosa people in the Transkei region of Eastern Cape, South Africa. Indian J Trad Med. 2014, 13: 292-298 PubMed .

2. Gurib-Fakim A. Medicinal plants: Traditions of yesterday and drugs of tomorrow. Mol Aspects Med. 2006; 27: 1-93 PubMed .

3. Van Wyk BE, van Oudtshoorn B, Gerick N. Medicinal plants of South Africa, 2nd edition. Briza publications. Pretoria. 2009; p366.

4. Blum D, Feachem RG. Measuring the Impact of Water Supply and Sanitation Investments on Diarrheal Diseases: Problems of Methodology. Int J Epidemiol. 1983; 12(3):357 PubMed -65.

5. Sekirov I, Russels SL, Antunes CA, Finlay BB. Gut Microbiota in Health and Disease. Physiol Rev. 2010; 90: 859-904.

6. Rabe T, van Staden J. Antibacterial activity of South African plants used for medicinal purpose. J Ethnopharmacol. 1997; 56: 81-87.
7. Tiwara BK,Valdramidis V P, O' Donnell C P, Muthukumarappan K, Bourke P, Cullen P J. Application of Natural Antimicrobials for Food Preservation. J Agric Food Chem. 2009; 57(14): 5987-6000.

8. Chen X-W, Serag ES, Sneed KB, Zhou S-F, Herbal bioactivation, molecular targets and the toxicity relevance. Chem-Biol Interact. 2011; 192:161-176.

9. Fennell CW, Lindsey KL, McGaw LJ, Sparg SG, Stafford GI, Elgorashi EE, Grace OM, van Staden J. Assessing African medicinal plants for efficacy and safety: pharmacological screening and toxicology. J Ethnopharmacol. 2004; 94: 205-217.

10. Ernst E. Risks of herbal medicinal products. Pharmacoepidemiol Drug Saf. 2004; 13: 767-771.

11. Wali UW, Uddin G, Siddiqui BS. Ethnic uses, Pharmacological and phytochemical profile of genus Grewia. J Asian Nat Prod Res. 2012; 14(2): 186-195.

12. Leistner OA. Seed plants of Southern Africa: families and genera. Strelizia 2000; 10.

13. Bowden BN. Tiliaceae, flowering plants of the world, Dod B (Eds). Oxford University Press, London, 90-91. 1978.

14. Curtis BA, Mannheime CA. Tree Atlas of Namibia National Botanic Research Institute, Windhoek. p.432433. 2005.

15. Mainah J. Distribution and association of Grewia flava with other species in the Kalahari environment. Botswana Notes and Records. 2001; 33:115-127

16. Kotze M, Ellof JN. Extraction of antibacterial compounds from Combretum microphyllum (Combrataceae). S. Afr J Botany. 2002; 68: 62-67 PubMed .

17. Dzoyem JP, McGaw LJ, Eloff JN. In vitro antibacterial, antioxidant and cytotoxic activity of acetone leaf extracts of nine under-investigated Fabaceae tree species 
leads to potentially useful extracts in animal health and productivity. BMC Complement Altern Med 2014, 14:147.

18. Masoko P, Eloff JN Screening of twenty-four South

African combretum and six terminalia species (combretaceae) for antioxidant activities. Afr J Tradit Complement Altern Med. 2007; 4 (2): 231-239

19. Brand-Williams W, Cuveleir ME, Berset C. Use of a free radical method to evaluate antioxidant activity. $L W T$ Food Sci Technol. 1995; 28:25-30 PubMed .

20. Eloff JN. Which extractant should be used for the screening and isolation of antimicrobial components from plants? J Ethnopharmacol. 1998; 60: 1-8.

21. Zia-U-Haq M, Stanković MS, Rizwan K, Feo VD. Grewia asiatica L., a food plant with multiple uses. Molecules. 2013; 18(3):2663 PubMed -82.

22. Gupta P, Sharma A, Verma AK. GC/MS profiling and antimicrobial effect of six Indian tropical fruit residues against clinically pathogenic bacterial strain. Int J Adv Pharm Res. 2012; 3: 1229-1235.
23. Taganna JC, Quanico JP, Perono RMG, Amor EC, Rivera WL. Tannin-rich fraction from Terminalia catappa inhibits quorum sensing (QS) in Chromobacterium violaceum and the QS-controlled biofilm maturation and LasA staphylolytic activity in Pseudomonas aeruginosa. $J$ Ethnopharmacol. 2011; 134: 865-871 PubMed

24. Chattopadhyay S, Pakrashi SC. Indian medicinal plants. XXXIV. Triterpenes from Grewia asiatica. J. Ind. Chem. Sci. 1975; 52: 55

25. Abou Zeid AHS, Sleem AA. Anti-hyperlipidemic effect and lipoidal constituents of Grewia asiatica L. leaves. Bull Natl Res Cent. 2005; 30: 557-573 PubMed

26. Asghar MN, Khan IU, Sherin L, Ashfaq M. Evaluation of antioxidant activity of Grewia asiatica berry using 2,2-azinobis-(3-ethylbenzoline-6-sulphonic acid) and N,N-dimethyl-p-phenylenediamine radical cations decolourazation assays. Asian J Chem. 2008; 20: 5123-5132 PubMed . 